\title{
A PALAEOTEMPERATURE RECORD FOR THE FINNISH LAKELAND BASED ON MICRODENSITOMETRIC VARIATIONS IN TREE RINGS
}

\author{
SAMULI HELAMA ${ }^{1}$, MATTI VARTIAINEN ${ }^{2}$, JARI HOLOPAINEN ${ }^{3}$, HANNA M. MÄKELÄ ${ }^{4}$, \\ TANELI KOLSTRÖM ${ }^{5}$ and JOUKO MERILÄINEN ${ }^{6}$ \\ ${ }^{I}$ Finnish Forest Research Institute, Northern Unit, Eteläranta 55, P.O. Box 16, 96301 Rovaniemi, Finland \\ ${ }^{2}$ Saima Centre for Environmental Sciences, Kuninkaankartanonkatu 5, P.O. Box 86, 57101 Savonlinna, Finland \\ ${ }^{3}$ Department of Geosciences and Geography, Gustaf Hällströmin katu 2a, P.O. Box 64, 00014 University of Helsinki, Finland \\ ${ }^{4}$ Finnish Meteorological Institute, Erik Palménin aukio 1, P.O. Box 503, 00101 Helsinki, Finland \\ ${ }^{5}$ Finnish Forest Research Institute, Yliopistokatu 6, P.O. Box 68, 80101 Joensuu, Finland \\ ${ }^{6}$ Kivelänkatu 2 B 5, 57200 Savonlinna, Finland
}

Received 4 December 2013

Accepted 4 April 2014

\begin{abstract}
X-ray based tree-ring data of maximum latewood densities (MXD) was combined for south-eastern Finland. This data originated from subfossil and modern pine (Pinus sylvestris L.) materials comprising a continuous dendroclimatic record over the past millennium. Calibrating and verifying the MXD chronologies against the instrumental temperature data showed a promising opportunity to reconstruct warm-season (May through September) temperature variability. A new palaeotemperature record correlated statistically significantly with the long instrumental temperature records in the region and adjacent areas since the 1740s. Comparisons with tree-ring based (MXD and tree-ring width) reconstructions from northern Fennoscandia and northern Finland exhibited consistent summer temperature variations through the Medieval Climate Anomaly, Little Ice Age, and the $20^{\text {th }}$ century warmth. A culmination of the LIA cooling during the early $18^{\text {th }}$ century appeared consistently with the Maunder Minimum, when the solar activity was drastically reduced. A number of coolest reconstructed events between AD 1407 and 1902 were coeval to years of crop failure and famine as documented in the agro-historical chronicles. Results indicate an encouraging possibility of warm-season temperature reconstructions using middle/south boreal tree-ring archives to detail and enhance the understanding of past interactions between humans, ecosystems and the earth.
\end{abstract}

Keywords: dendroclimatology, geochronology, Maunder Minimum, Medieval Climate Anomaly, Little Ice Age, crop failure.

\section{INTRODUCTION}

Tree rings provide incremental records of late Quaternary climate variability (Fritts, 1976; Bradley, 1999; Walker, 2005). In comparison to many other types of proxies, the benefits of tree rings as palaeoclimate records

Corresponding author: S. Helama

e-mail: samuli.helama@metla.fi

ISSN 1897-1695 (online), 1733-8387 (print)

(C) 2013 Silesian University of Technology, Gliwice, Poland.

All rights reserved. involve their dating to exact calendar years and temporal calibration with meteorological series (Helama et al., $2010 b)$. Yet, a temporal extension of the modern chronology can be achieved by the additional use of historical, archaeological or paleontological wood using dendrochronological dating methods. In Fennoscandia, longest chronologies have been constructed from subfossil pine trunks preserved in sedimentary archives of small 
lakes or bogs (Eronen et al., 1999, 2002; Helama et al., 2008a; Grudd et al., 2000, 2002 and Linderholm and Gunnarson 2005). These chronologies originate from regions near the timberline where tree growth is predominantly governed by summer temperature. In consequence of their cold habitat, the tree-ring width chronologies provide excellent proxy records of past temperature variability (Grudd et al., 2002; Helama et al., 2002, 2009a, 2009b, 2010a, 2010b, 2012b; Linderholm and Gunnarson, 2005). In many regions, however, an improved dendroclimatic signal of summer temperature can be attained using X-ray based microdensitometric series of maximum latewood densities (MXD), rather than using annual widths of the rings (Briffa et al., 1988, 2002a, 2002b). This dendroclimatic connection has been exploited also in the mountainous and timberline areas of Fennoscandia where the MXD chronologies have been exploited for summer temperature reconstructions to detail the past climate variability through the Common Era (Schweingruber et al., 1988; Briffa et al., 1988, 1992; Grudd 2008; Büntgen et al., 2011; Gunnarson et al., 2011; Esper et al., 2012).

Construction of long chronologies is also possible for more southern regions, either similarly using naturally preserved wood or by utilizing samples from historical buildings (Bartholin, 1987; Läänelaid and Eckstein, 2003; Koprowski et al., 2012). In south-eastern Finland, subfossil wood materials have been recovered from a number of lakes. These materials comprise a tree-ring chronology spanning over the past fifteen centuries (Lindholm et al. 1998-1999; Helama et al., 2005a). Moreover, tree rings of this chronology have recently been exposed for X-ray based microdensitometric analyses (Helama et al., 2008b, 2010c). Recent dendroclimatic analyses of these MXD data evidenced a distinct summer temperature signal (Helama et al., 2012a). It appears that this dendrodensitometric data provide a promising palaeoclimate opportunity to reconstruct summer temperature variations in south-eastern Finland. It fills the hitherto existing void in millennium-long temperature reconstructions in low-land areas and south of the Fennoscandian timberline zone. The aim of the paper is the temperature reconstruction in middle/south boreal zone in Finland. All available MXD data was combined for a summer temperature reconstruction for southern Finland, particularly the Finnish Lakeland, over the last centuries and the past millennium. The recently produced MXD data at the University of Eastern Finland (Helama et al., 2008b, 2010c, 2012a) is complemented by dendrodensitometric data available from digital tree-ring database (Grissino-Mayer and Fritts, 1997) as already collected in the area in the 1970s (Schweingruber et al., 1987, 1991). Standardizing the MXD data and calibrating the obtained MXD chronologies against the instrumental summer temperature records yield a new palaeotemperature curve that helps us to throw light on late Holocene climate evolution in the district where no such reconstruction yet exist. Con- trasting the new palaeoclimate information with existing tree-ring based summer temperature reconstructions from northern Finland and Fennoscandia (Helama et al., 2009a, 2009b, 2010a; Esper et al., 2012) enables the north-south comparison of temperature variations on annual resolution. It outlines the spatial palaeoclimate variations in the region where previous palaeoclimate research have highlighted notable climatic shifts through the Medieval Climate Anomaly to Little Ice Age (Grudd et al., 2002; Helama et al., 2005b, 2009a, 2009b, 2010a; Gunnarson et al., 2011; Esper et al., 2012) during the past thirteen centuries.

\section{MATERIAL AND METHODS}

\section{Study region}

Our study material comprise three separate tree-ring chronologies of Scots pine (Pinus sylvestris L.) denoted hereafter using their abbreviated site names: Savonlinna (SA), Pyhä-Häkki (PH) and Petkeljärvi (PJ). The forests of this area belong to the south/middle boreal zones (Ahti et al., 1968) roughly between 75 and 185 metres above sea level (Fig. 1). The coniferous timberline in northern Finland is located approx. $800 \mathrm{~km}$ north of the studied sites.

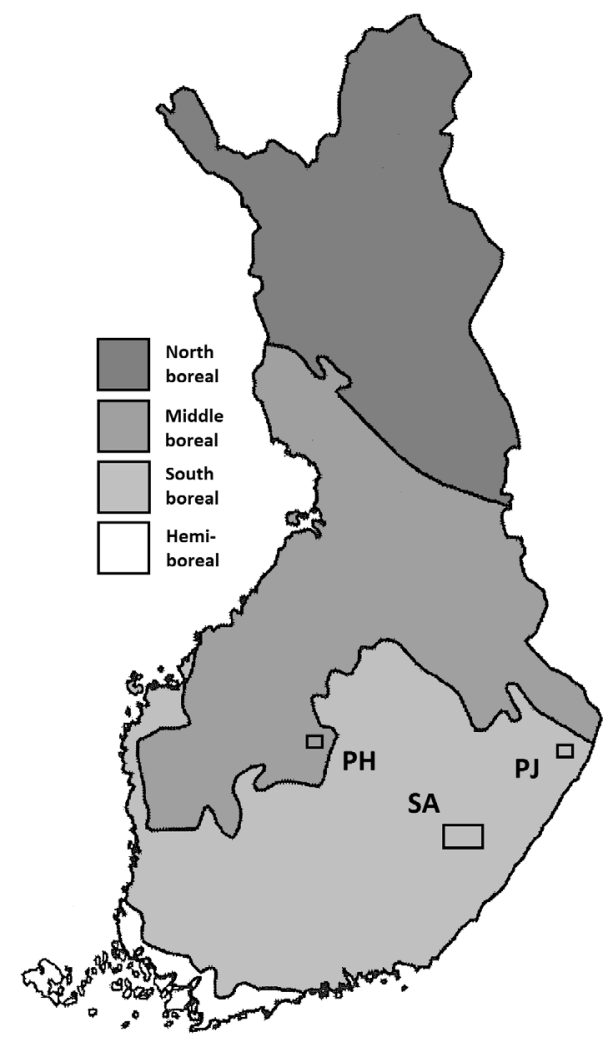

Fig. 1. A map of Finland and the locations of the studied tree-ring chronologies in the region of Savonlinna (SA) and in the national parks of Pyhä-Häkki (PH), and Petkeljärvi (PJ), in relation to the vegetation zones (redrawn after Virkkala et al., 2000). 


\section{Acquiring the MXD data}

The wood material for the SA chronology has been collected near the city of Savonlinna. Living trees were harvested in Varparanta $\left(61^{\circ} 59^{\prime} \mathrm{N}\right.$; $28^{\circ} 45^{\prime} \mathrm{E}, 80 \mathrm{~m}$ a.s.l.) and Punkaharju $\left(61^{\circ} 48^{\prime} \mathrm{N}\right.$; $29^{\circ} 19^{\prime} \mathrm{E}, \quad 80-90 \mathrm{~m}$ a.s.l.). Subfossil samples of Scots pine were retrieved from lacustrine sediment of Lake Herajärvi (61 ${ }^{\circ} 58^{\prime} \mathrm{N}$; $\left.28^{\circ} 50^{\prime} \mathrm{E}\right)$, Kaivanto (61 $56^{\circ} \mathrm{N}$; $\left.28^{\circ} 59^{\prime} \mathrm{E}\right)$, Liippilampi $\left(61^{\circ} 55^{\prime} \mathrm{N}\right.$; $\left.29^{\circ} 02^{\prime} \mathrm{E}\right), \quad$ Isokortteikko $\left(61^{\circ} 58^{\prime} \mathrm{N}\right.$; $\left.28^{\circ} 52^{\prime} \mathrm{E}\right)$ and

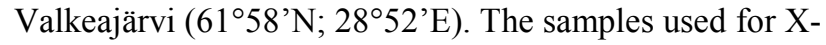
ray microdensitometry represent a subset of a much larger subfossil sample assemblage (Lindholm et al., 19981999; Meriläinen and Timonen, 2004; Helama et al., 2005a). The sample cross-dating, following the dendrochronological procedures of Aniol (1983) and Holmes (1983), along with visual comparison of the produced time series, was implemented using the ring-width data of existing tree-ring chronology of the region (Lindholm et al., 1998-1999; Helama et al., 2005a). The subsequent microdensitometric analyses and the determination of the MXD data were carried out using the published routines (Helama et al., 2008b, 2010c, 2012a). The samples were acclimatized to ambient temperature of $20.1-20.9^{\circ} \mathrm{C}$ and relative humidity of $61.0-62.0 \%$, corresponding to wood moisture content of roughly $12 \%$. Extractives were not removed. The X-ray microdensitometry (ITRAX) scanning (Bergsten et al., 2001) was done using a step size of $25 \mu \mathrm{m}$ intervals with the following settings for tube: voltage of $30 \mathrm{kV}$, current value of $25 \mathrm{~mA}$ and an exposure time of $20 \mathrm{~ms}$ (Peltola et al., 2007). The first year of the SA chronology occurs in AD 673. The sample size varies through time and there is actually no data available between the subfossil and living-tree MXD chronologies, AD 1810-1850 (Fig. 2). This chronology terminates in AD 2000.

The MXD data of the PH $\left(62^{\circ} 51^{\prime} \mathrm{N} ; 25^{\circ} 29^{\prime} \mathrm{E}\right)$ and PJ $\left(62^{\circ} 35^{\prime} \mathrm{N} ; 31^{\circ} \mathrm{N} 10^{\prime} \mathrm{E}\right)$ chronologies originate from the sites that locate in national parks in southern Finland (Lappalainen, 2001; Virkkala et al., 2000). The material of PH and PJ chronologies was originally collected in the 1970s (Schweingruber et al., 1987, 1991) and has been used as a part of several previously published largescale/hemispheric tree-ring based climate assessments (e.g. Schweingruber et al., 1991; Briffa et al., 2002a, 2002b). These data was downloaded via online database (GrissinoMayer and Fritts, 1997) under the site (file) names of "Pyhan Hakin National Park" (finl010) and "Haaparava National Park" (finl014), respectively.

\section{Building the palaeotemperature record}

While the SA and $\mathrm{PH} / \mathrm{PJ}$ datasets were produced analogously, the actual methods differed in detail. The way of taking control of wood moisture and extractive contents varied. Also, the measurement step size of density scanning was not equal. All these fine details may reduce comparability between the MXD series (Grudd,
2008; Helama et al., 2010c, 2012a; Gunnarson et al., 2011) and we thus followed the previously proposed implementation of conceivably heterogeneous microdensitometric data by separately modelling the cambial (i.e., non-climatic) growth trends within the two datasets (Helama et al., 2012a). In a similar study updating historical database acquired MXD data by recently collected series, Gunnarson et al. (2011) determined two cambial growth curves individually for both MXD datasets to remove their non-climatic growth trends. Moreover, the $\mathrm{SA}, \mathrm{PH}$ and PJ chronologies were exploited as separate regressors in building the palaeoclimatic transfer functions through multiple regression. Following these guidelines (see Helama et al., 2012a), the non-climatic growth trends in MXD series due to tree ageing were removed using the regional curve standardization (Briffa et al., 1992) applied separately to SA and PH/PJ datasets (Fig. $3)$. Each series were aligned according to their ring numbers. An average curve was calculated as an arithmetic mean of all available density values. This trend was further modelled using the function that has been used in dendrochronology, for example, by Warren (1980). That is:

$$
y=a x^{b} e^{-c x}+d
$$

where $a, b, c$ and $d$ are coefficients of the nonlinear trend as a function of tree age $x$. Once the expected growth trend was estimated, the initial measurement series were detrended by extracting the dimensionless tree-ring indices from the expected growth curve by subtraction (Helama et al., 2008b). The tree-ring chronology was produced by averaging the cross-dated series into the mean chronologies by bi-weight robust mean procedure (Cook et al., 1990). The variance of the tree-ring chronology was stabilized using the method of Osborn et al. (1997).

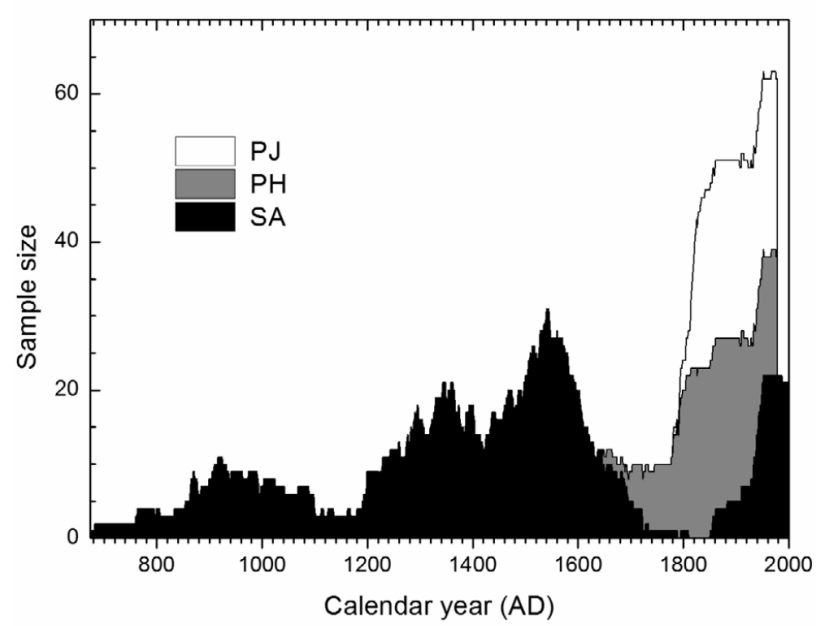

Fig. 2. Temporal variations in the chronology sample size (a number of cross-dated tree-ring series per year) in the chronologies of Savonlinna (SA), Pyhä-Häkki (PH), and Petkeljärvi (PJ). 

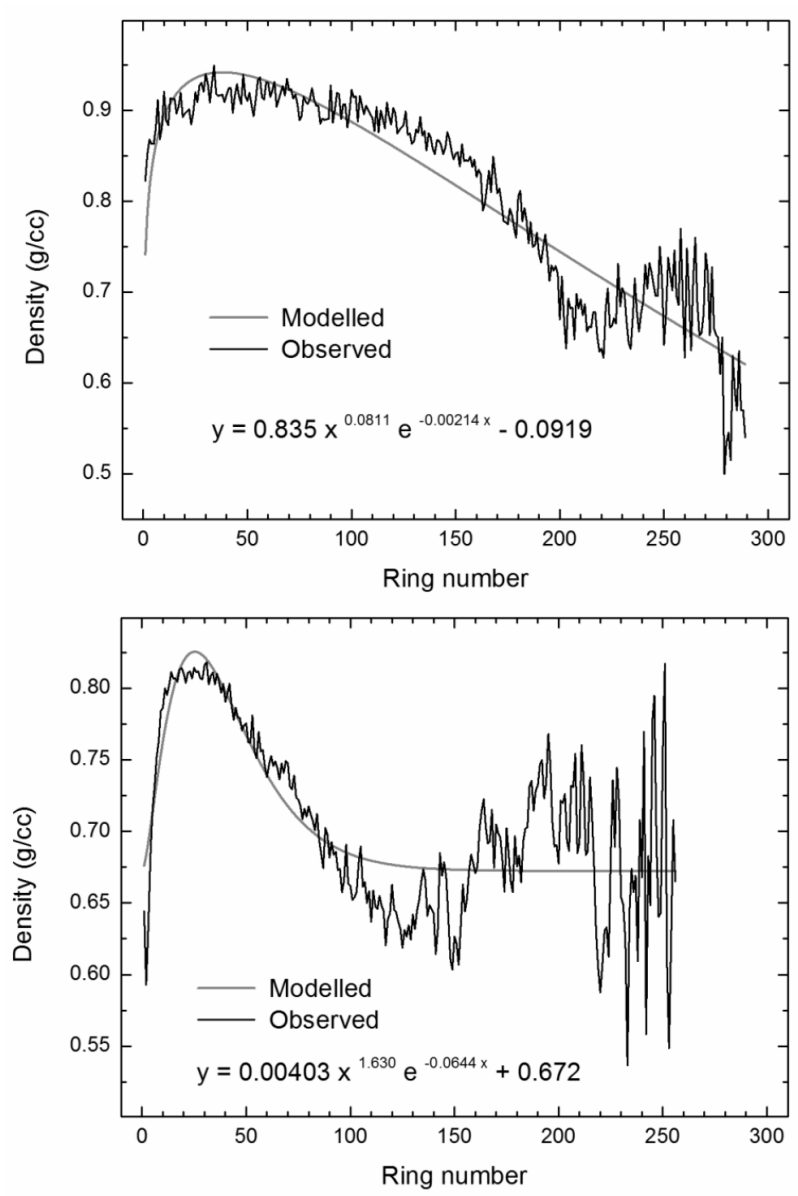

Fig. 3. Determination of observed and modelled (Eq. 2.1) mean growth curves using maximum density (MXD) data calculated from values of Savonlinna (SA), Pyhä-Häkki (PH), and Petkeljärvi (PJ) data. The coefficient of determination ( $\left.R^{2}\right)$ shows the observed (black line) variance explained by the models (grey line).

The Punkaharju weather station $\left(61^{\circ} 48^{\prime} \mathrm{N} ; 2^{\circ} 20^{\prime} \mathrm{E}\right)$ provided the instrumental series of monthly mean temperatures for the dendroclimatic analyses. Obtaining the transfer functions, the MXD chronologies were regressed against the instrumental climate to depict temperature variations in Celsius scale. A multiple linear regression was applied. Tree-ring chronologies and temperature time-series provided the independent and dependent data, respectively. Tree-ring chronologies often contain high autocorrelation (Fritts, 1976) exceeding the autocorrelation observed in climatic time-series and, consequently, the transfer function may benefit from using tree-ring values of several years $(t-n, t, t+n)$ as independent variables in regression, in order to estimate the climate in year $(t)$ (Helama et al., 2009a). Here we used multiple linear regression with tree-ring values in years $t-1, t$, and $t+1$. All three chronologies contained at least five pines (Läänelaid, 2000) for the period AD 1883-1978 (see Fig. 2), whereas both the PH and PJ chronologies covered also the period AD 1805-1882. Only the PH chronology spanned over the AD 1705-1884 interval, whereas the SA and PH chronologies contained at least five trees also in AD 1703 and 1704. Prior to that date, only the SA chronology showed the required sample size. Thus, the calibration/verification statistics were performed for five combinations of proxy sets including SA, $\mathrm{PH}, \mathrm{SA} / \mathrm{PH}, \mathrm{PH} / \mathrm{PJ}$ and $\mathrm{SA} / \mathrm{PH} / \mathrm{PJ}$ chronologies. Acceptable models were chosen with a stepwise selection procedure with the criteria for predictor entry and removal at an F-statistic probability of $<0.05$ and $<0.10$, respectively. The coefficient of determination $\left(\mathrm{R}^{2}\right)$ was computed over the calibration (first, 1905-1941) period. Statistics calculated over the verification period (first, 19421978) were the squared correlation coefficient $\left(r^{2}\right)$, reduction of error (RE) and coefficient of efficiency (CE) (Fritts, 1976; Briffa et al., 1988).

Evaluation of the temporal stability of the relationship between the MXD data and climate was carried out using a cross-calibration/verification procedure (Gordon et al., 1982; Briffa et al., 1988) over the periods 1942-1978 and 1905-1941 for calibration and verification purposes, respectively. Significance of the dendroclimatic statistics was calculated using a combination of frequency-domain modelling (Ebisuzaki, 1997) and Monte Carlo (Efron and Tibshirani, 1986) methods. One thousand (1000) pairs of surrogate time series with the same power spectrum as the original time series but with a random phase were generated and their corresponding statistics calculated. The empirical probability distribution of each statistic value was calculated and, hence, its significance for the single-tailed $\left(\mathrm{R}^{2}, \mathrm{r}^{2}, \mathrm{RE}\right.$ and $\left.\mathrm{CE}\right)$. This method is robust as it accounts for autocorrelation structure in the time series (Ebisuzaki, 1997; Macias Fauria et al., 2010, Macias-Fauria et al., 2012). The palaeoclimate model showing a combination of robust calibration and verification statistics was chosen as a final model of warmseason temperatures that was calibrated over the common period (1905-1978). Finally, the past temperature variability was reconstructed using the dendrochronological information over the full length of the chronologies. For each reconstruction, confidence intervals were calculated at $99 \%$ thresholds from the autoregressive structure of the residuals of each transfer function. The confidence intervals were based on generating 1000 surrogate series of residuals with the same autoregressive structure as the residuals from each regression using a Matlab-based program (Macias-Fauria et al., 2012). The differing reconstructed temperature variances (indicated by their standard deviations over the calibration period) were adjusted by scaling them to a standard deviation of temperature record over the calibration period. Instead of merely averaging the reconstructions, we excerpted each annual temperature estimate from the (combination of) reconstruction(s) showing strongest correspondence to climate with at least five trees in each chronology comprising the particular reconstruction (see above). That is, the palaeotemperature record was obtained as a combina- 
tion of individual re-scaled warm-season temperature reconstructions.

\section{Proxy comparisons}

In order to obtain the longest possible temperature time series for the study area, the Finnish monthly mean temperature grid data (Tietäväinen et al., 2010) was used to estimate the mean monthly temperatures for a grid point representing the site of the Punkaharju meteorological station. The grid data provides temperature values for the site since the year AD 1883. Prior to this date, the monthly grid-point mean temperatures were judged unbiased following the elevated number of station records in the region (Tietäväinen et al., 2010). Long instrumental summer temperature records were also available in adjacent areas from St. Petersburg (Jones and Lister, 2002) in north-western Russia (since AD 1743), Turku (Holopainen, 2004) in south-western Finland (AD 1749-1822 and since AD 1873), and Uppsala (since AD 1748) and Stockholm (since AD 1756) in Sweden (Moberg and Bergström, 1997). The record from St. Petersburg had missing values in 1801-1804, 1992-1994 and 2001. Summer temperature reconstructions from northern Finland and northern Fennoscandia were available over the study period, based on tree-ring width (Helama et al., 2009a, 2009b, 2010a) and MXD data (Esper et al., 2012), respectively. These records were filtered using a spline function (Cook and Peters, 1981) with the rigidity of 50years $(50 \%$ frequency cut-off) and compared with the new palaeoclimate evidence by visual inspection and Pearson correlations (r). Significance of the correlations was obtained using Monte Carlo methods (Burg, 1978; Macias Fauria et al., 2010, Macias-Fauria et al., 2012).

\section{RESULTS}

\section{Effect of temperature}

Dendroclimatic correlations over the calibration period evidenced that the MXD chronologies exhibit a common signal of warm-season temperatures (Fig. 4a). The season with highest correlations occurred for months from May to August, more broadly from April to September. This pattern was confirmed by correlations with mean multi-monthly temperature parametres. It was observed that highest correlations, indicative of the skill for a palaeotemperature reconstruction, was obtained for multi-monthly temperature data of April through September, May through September, April through August, and May through August seasons (Fig. 4b). These four seasons were selected as the target seasons for examinations of calibration and verification statistics.

\section{Temperature reconstruction and long-term instru- mental records}

Calibration and verification statistics showed that the MXD data provided temperature reconstructions that correlated statistically significantly $\left(\mathrm{R}^{2}, \mathrm{r}^{2}\right)$ with the instrumentally observed temperature variations over both sub-periods (Table 1). The results from RE and CE tests showed, however, that some of the reconstructions did not verify satisfactory for April through September, April through August and May through August seasons. Particularly, the reduced skill of reconstructions was observed over the late period (AD 1942-1978) in comparison to the early period (AD 1905-1941). Also the correlations between the reconstructions and the instrumentally observed temperatures were generally weaker over this period. Yet, the temperature reconstructions of May through September season exhibited statistically significant $(p<0.05)$ calibration and verification results over both the early and late periods (Table 1). This season was therefore selected as the season of reconstruction for further palaeoclimate analyses of warm-season temperature variability.
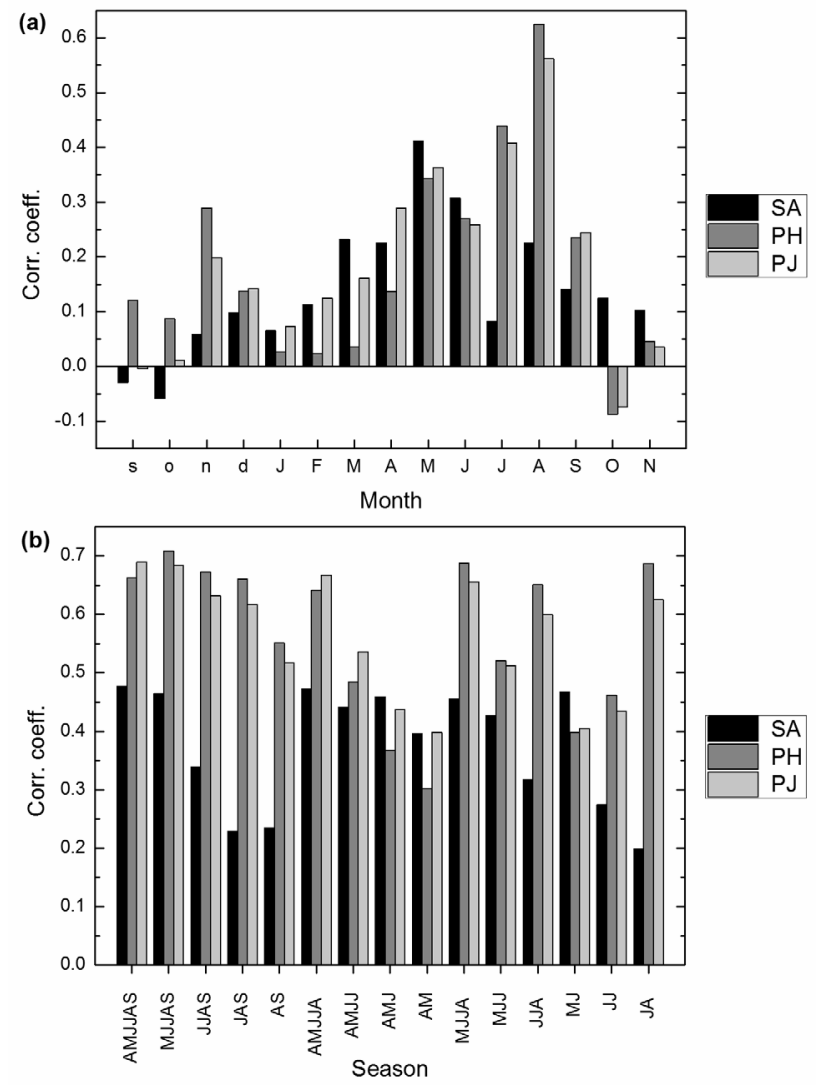

Fig. 4. Pearson correlations over the calibration period (1905-1978) between the monthly (a) and multi-monthly (b) mean temperatures of previous (lower case letters) and concurrent (upper case letter) to year of growth in the maximum density (MXD) chronologies of Savonlinna (SA), Pyhä-Häkki (PH) and Petkeljärvi (PJ). 
Table 1. Calibration and verification statistics. Early (AD 1905-1941) calibration/late (AD 1942-1978) verification (a) and late calibration/early verification (b) procedures carried out using the MXD chronologies of Savonlinna (SA), Pyhä-Häkki (PH) and Petkeljärvi (PJ) as proxies for warm-season temperatures of different monthly composites: April (A), May (M), June-July (JJ), August (A) and September (S). Calibration is quantified using the coefficient of determination $\left(R^{2}\right)$ and verification using the squared correlation coefficient $\left(r^{2}\right)$, the reduction of error (RE) and the coefficient of efficiency (CE) - statistics with their obtained Monte Carlo based statistical significance (p).

\begin{tabular}{|c|c|c|c|c|c|c|}
\hline & Season & Model & $\begin{array}{c}R^{2}(p) \\
1905-1941\end{array}$ & $\begin{array}{c}r^{2}(p) \\
1942-1978\end{array}$ & $\begin{array}{c}\mathrm{RE}(p) \\
1942-1978\end{array}$ & $\begin{array}{c}C \mathrm{CE}(\mathrm{p}) \\
1942-1978\end{array}$ \\
\hline \multirow[t]{4}{*}{ (a) } & AMJJAS & $\begin{array}{c}\mathrm{SA}_{\mathrm{t}}, \mathrm{SA}_{\mathrm{t}-1} \\
\mathrm{PH}_{\mathrm{t}} \\
\mathrm{SA}_{\mathrm{t}}, \mathrm{PH}_{\mathrm{t}} \\
\mathrm{PH}_{\mathrm{t}} \mathrm{P} \mathrm{PJ}_{\mathrm{t}} \\
\mathrm{SA}_{\mathrm{t}}, \mathrm{PH}_{\mathrm{t}}, \mathrm{PJ}_{\mathrm{t}}\end{array}$ & $\begin{array}{l}0.202(0.0114) \\
0.526(<0.001) \\
0.638(<0.001) \\
0.646(<0.001) \\
0.680(<0.001)\end{array}$ & $\begin{array}{l}0.259(0.0015) \\
0.345(<0.001) \\
0.380(<0.001) \\
0.440(<0.001) \\
0.441(<0.001)\end{array}$ & $\begin{array}{c}0.307(0.0008) \\
0.204(0.0012) \\
0.063(0.1067) \\
0.124(0.0211) \\
0.251(0.001)\end{array}$ & $\begin{array}{c}0.208(<0.001) \\
0.091(0.0042) \\
-0.070(0.2671) \\
-0.001(0.1097) \\
0.144(0.0029)\end{array}$ \\
\hline & AMJJA & $\begin{array}{c}\mathrm{SA}_{\mathrm{t}}, \mathrm{SA}_{\mathrm{t}-1} \\
\mathrm{PH}_{\mathrm{t}} \\
\mathrm{SA}_{\mathrm{t}}, \mathrm{PH}_{\mathrm{t}} \\
\mathrm{PH}_{\mathrm{t}} \mathrm{P} \mathrm{PJ}_{\mathrm{t}} \\
\mathrm{SA}_{\mathrm{t}}, \mathrm{PH}_{\mathrm{t}}, \mathrm{PJ}_{\mathrm{t}}\end{array}$ & $\begin{array}{l}0.212(0.0072) \\
0.562(<0.001) \\
0.680(<0.001) \\
0.679(<0.001) \\
0.717(<0.001)\end{array}$ & $\begin{array}{l}0.226(0.0064) \\
0.249(<0.001) \\
0.286(<0.001) \\
0.327(<0.001) \\
0.331(<0.001)\end{array}$ & $\begin{array}{c}0.257(0.0013) \\
0.022(0.1394) \\
-0.147(0.7914) \\
-0.040(0.5494) \\
0.053(0.0951)\end{array}$ & $\begin{array}{c}0.168(0.0015) \\
-0.095(0.5192) \\
-0.284(0.8271) \\
-0.165(0.6514) \\
-0.061(0.261)\end{array}$ \\
\hline & MJJAS & $\begin{array}{c}\mathrm{SA}_{\mathrm{t}}, \mathrm{SA}_{\mathrm{t}-1} \\
\mathrm{PH}_{\mathrm{t}} \\
\mathrm{SA}_{\mathrm{t}}, \mathrm{PH}_{\mathrm{t}} \\
\mathrm{PH}_{\mathrm{t}} \mathrm{P} \mathrm{PJ}_{\mathrm{t}} \\
\mathrm{SA}_{\mathrm{t}}, \mathrm{PH}_{\mathrm{t}}, \mathrm{PJ}_{\mathrm{t}}\end{array}$ & $\begin{array}{l}0.286(0.0081) \\
0.587(<0.001) \\
0.679(<0.001) \\
0.667(<0.001) \\
0.701(<0.001)\end{array}$ & $\begin{array}{l}0.227(0.0045) \\
0.412(<0.001) \\
0.443(<0.001) \\
0.465(<0.001) \\
0.473(<0.001)\end{array}$ & $\begin{array}{l}0.295(<0.001) \\
0.276(<0.001) \\
0.152(0.0149) \\
0.227(0.0026) \\
0.292(<0.001)\end{array}$ & $\begin{array}{l}0.210(<0.001) \\
0.189(<0.001) \\
0.049(0.0239) \\
0.133(0.0013) \\
0.207(0.0006)\end{array}$ \\
\hline & MJJA & $\begin{array}{c}\mathrm{SA}_{\mathrm{t}}, \mathrm{SA}_{\mathrm{t}-1} \\
\mathrm{PH}_{\mathrm{t}} \\
\mathrm{SA}_{\mathrm{t}}, \mathrm{PH}_{\mathrm{t}} \\
\mathrm{PH}_{\mathrm{t}} \mathrm{P} \mathrm{PJ}_{\mathrm{t}} \\
\mathrm{SA}_{\mathrm{t}}, \mathrm{PH}_{\mathrm{t}}, \mathrm{PJ}_{\mathrm{t}}\end{array}$ & $\begin{array}{l}0.282(0.0078) \\
0.649(<0.001) \\
0.745(<0.001) \\
0.722(<0.001) \\
0.762(<0.001)\end{array}$ & $\begin{array}{c}0.258(0.0012) \\
0.286(0.003) \\
0.318(0.0005) \\
0.324(<0.001) \\
0.336(<0.001)\end{array}$ & $\begin{array}{l}0.318(<0.001) \\
0.065(0.0641) \\
-0.081(0.571) \\
0.034(0.1332) \\
0.054(0.1116)\end{array}$ & $\begin{array}{c}0.254(<0.001) \\
-0.023(0.2537) \\
-0.182(0.596) \\
-0.056(0.2976) \\
-0.035(0.1849)\end{array}$ \\
\hline \multirow[t]{4}{*}{ (b) } & AMJJAS & $\begin{array}{c}\mathrm{SA}_{\mathrm{t}}, \mathrm{SA}_{\mathrm{t}-1} \\
\mathrm{PH}_{\mathrm{t}} \\
\mathrm{SA}_{\mathrm{t}}, \mathrm{PH}_{\mathrm{t}} \\
\mathrm{PH}_{\mathrm{t}} \mathrm{P} \mathrm{PJ}_{\mathrm{t}} \\
\mathrm{SA}_{\mathrm{t}}, \mathrm{PH}_{\mathrm{t}}, \mathrm{PJ}_{\mathrm{t}} \\
\end{array}$ & $\begin{array}{c}0.259(0.0015) \\
0.345(<0.001) \\
0.385(0.0007) \\
0.44(<0.001) \\
0.446(<0.001)\end{array}$ & $\begin{array}{l}0.202(0.0114) \\
0.526(<0.001) \\
0.607(<0.001) \\
0.646(<0.001) \\
0.674(<0.001)\end{array}$ & $\begin{array}{l}0.196(0.0042) \\
0.429(<0.001) \\
0.513(<0.001) \\
0.482(<0.001) \\
0.544(<0.001)\end{array}$ & $\begin{array}{l}0.114(0.0034) \\
0.391(<0.001) \\
0.481(<0.001) \\
0.448(<0.001) \\
0.514(<0.001)\end{array}$ \\
\hline & AMJJA & $\begin{array}{c}\mathrm{SA}_{\mathrm{t}}, \mathrm{SA}_{\mathrm{t}-1} \\
\mathrm{PH}_{\mathrm{t}} \\
\mathrm{SA}_{\mathrm{t}}, \mathrm{PH}_{\mathrm{t}} \\
\mathrm{PH}_{\mathrm{t}} \mathrm{PJ}_{\mathrm{t}} \\
\mathrm{SA}_{\mathrm{t}}, \mathrm{PH}_{\mathrm{t}}, \mathrm{PJ}_{\mathrm{t}} \\
\end{array}$ & $\begin{array}{l}0.226(0.0064) \\
0.249(<0.001) \\
0.299(0.0019) \\
0.327(0.0022) \\
0.341(0.0044)\end{array}$ & $\begin{array}{l}0.212(0.0072) \\
0.562(<0.001) \\
0.583(<0.001) \\
0.677(<0.001) \\
0.678(<0.001)\end{array}$ & $\begin{array}{c}0.208(0.0013) \\
0.41(<0.001) \\
0.483(<0.001) \\
0.464(<0.001) \\
0.538(<0.001) \\
\end{array}$ & $\begin{array}{l}0.161(0.0017) \\
0.375(<0.001) \\
0.453(<0.001) \\
0.432(<0.001) \\
0.511(<0.001) \\
\end{array}$ \\
\hline & MJJAS & $\begin{array}{c}\mathrm{SA}_{\mathrm{t}}, \mathrm{SA}_{\mathrm{t}-1} \\
\mathrm{PH}_{\mathrm{t}} \\
\mathrm{SA}_{\mathrm{t}}, \mathrm{PH}_{\mathrm{t}} \\
\mathrm{PH}_{\mathrm{t}}, \mathrm{PJ}_{\mathrm{t}} \\
\mathrm{SA}_{\mathrm{t}}, \mathrm{PH}_{\mathrm{t}}, \mathrm{PJ}_{\mathrm{t}} \\
\end{array}$ & $\begin{array}{l}0.246(0.0175) \\
0.412(<0.001) \\
0.447(<0.001) \\
0.466(<0.001) \\
0.476(<0.001)\end{array}$ & $\begin{array}{l}0.263(0.0045) \\
0.587(<0.001) \\
0.653(<0.001) \\
0.667(<0.001) \\
0.695(<0.001)\end{array}$ & $\begin{array}{c}0.287(<0.001) \\
0.495(<0.001) \\
0.556(<0.001) \\
0.531(<0.001) \\
0.59(<0.001) \\
\end{array}$ & $\begin{array}{c}0.245(<0.001) \\
0.465(<0.001) \\
0.53(<0.001) \\
0.504(<0.001) \\
0.565(<0.001)\end{array}$ \\
\hline & MJJA & $\begin{array}{c}\mathrm{SA}_{\mathrm{t}}, \mathrm{SA}_{\mathrm{t}-1} \\
\mathrm{PH}_{\mathrm{t}} \\
\mathrm{SA}_{\mathrm{t}}, \mathrm{PH}_{\mathrm{t}} \\
\mathrm{PH}_{\mathrm{t}, \mathrm{PJ}} \\
\mathrm{SA}_{\mathrm{t}}, \mathrm{PH}_{\mathrm{t}}, \mathrm{PJ}_{\mathrm{t}}\end{array}$ & $\begin{array}{c}0.274(0.006) \\
0.286(0.003) \\
0.33(0.0013) \\
0.324(0.0017) \\
0.344(0.002)\end{array}$ & $\begin{array}{l}0.262(0.0036) \\
0.649(<0.001) \\
0.648(<0.001) \\
0.722(<0.001) \\
0.704(<0.001)\end{array}$ & $\begin{array}{c}0.277(<0.001) \\
0.49(<0.001) \\
0.532(<0.001) \\
0.525(<0.001) \\
0.577(<0.001)\end{array}$ & $\begin{array}{c}0.24(<0.001) \\
0.464(<0.001) \\
0.508(<0.001) \\
0.5(<0.001) \\
0.555(<0.001)\end{array}$ \\
\hline
\end{tabular}

Over the full calibration period (AD 1905-1978), the transfer function models explained around 30 to 60 percent of the instrumentally observed warm-season temperature variance (Table 2; Fig. 5). All obtained coefficients of determination $\left(\mathrm{R}^{2}\right)$ appeared statistically highly significant $(p<0.001)$. The five reconstructions, based on different combinations of tree-ring chronologies, showed a strong common palaeoclimate signal with mean correlation between the reconstructions averaging 0.798 over the calibration period (Table 3 ). The transfer functions were applied over the earlier periods to obtain new tree-ring based palaeoclimate information of warm-season temperature variability (Fig. 6). These records were further combined into a solitary palaeotemperature record (Fig. 7a). The new reconstruction evidenced variable temperatures over the full reconstruction period. Long-term temperature evolution implied a prevalence of warm temperatures during the $9^{\text {th }}, 11^{\text {th }}, 14^{\text {th }}$ and $20^{\text {th }}$ centuries, with several indications of warmest years during those centuries (Table 4). The warmest 50- and 250-year periods occurred in AD 1042-1091 and AD 862-1111, respectively. The coolest spells were obvious especially 
Table 2. Calibration of the tree-ring proxies over the common period (AD 1905-1978). Reconstructions of the warm season temperature variability were quantified using the coefficient of determination $\left(R^{2}\right)$, mean $(M)$, and standard deviation $(S D)$ of the reconstructed and instumental temperatures. Transfer functions were determined through the regression coefficients for the MXD chronologies of Savonlinna (SA), Pyhä-Häkki (PH) and Petkeljärvi $(P J)$ in their growth year concurrent $\left(t_{0}\right)$ and previous ( $\left.t_{-1}\right)$ to climate, and with a regression constant. All coefficients of determination $\left(R^{2}\right)$ were statistically significant $(p<0.001)$.

\begin{tabular}{|c|ccc|c|}
\hline Model & $\mathbf{R}^{2}$ & $\mathbf{M}$ & $\mathbf{S D}$ & Transfer function \\
\hline $\mathrm{SA}_{\mathrm{t}}, \mathrm{SA}_{\mathrm{t}-1}$ & 0.279 & 12.739 & 0.497 & $5.216 \mathrm{SA}_{\mathrm{t}}-2.734 \mathrm{SA}_{\mathrm{t}-1}+10.944$ \\
\hline $\mathrm{PH}_{\mathrm{t}}$ & 0.501 & 12.739 & 0.650 & $9.702 \mathrm{PH}_{\mathrm{t}}+3.434$ \\
\hline $\mathrm{SA}_{\mathrm{t}}, \mathrm{PH}_{\mathrm{t}}$ & 0.558 & 12.739 & 0.686 & $2.122 \mathrm{SA}_{\mathrm{t}}+8.496 \mathrm{PH}_{\mathrm{t}}+2.545$ \\
\hline $\mathrm{PH}_{\mathrm{t}}, \mathrm{PJ}_{\mathrm{t}}$ & 0.557 & 12.739 & 0.685 & $6.282 \mathrm{PH}_{\mathrm{t}}+5.685 \mathrm{PJ}_{\mathrm{t}}+0.894$ \\
\hline $\mathrm{SA}_{\mathrm{t}}, \mathrm{PH}_{\mathrm{t}}, \mathrm{PJ}_{\mathrm{t}}$ & 0.591 & 12.739 & 0.706 & $1.745 \mathrm{SA}+6.040 \mathrm{PH}_{\mathrm{t}}+4.434 \mathrm{PJ}_{\mathrm{t}}+0.720$ \\
\hline Instrumental & $\mathrm{n} / \mathrm{a}$ & 12.739 & 0.918 & $\mathrm{n} / \mathrm{a}$ \\
\hline
\end{tabular}
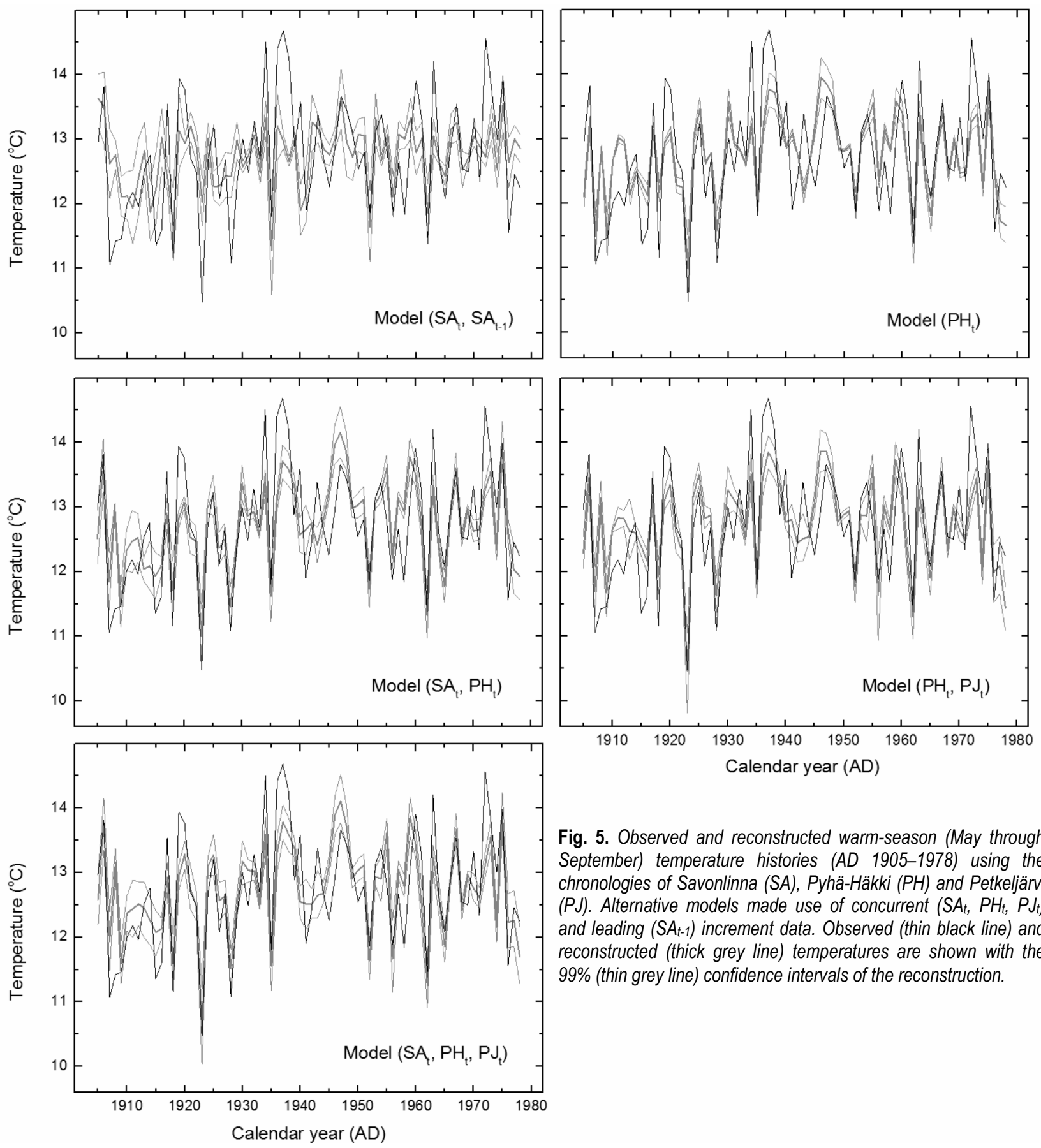

Fig. 5. Observed and reconstructed warm-season (May through September) temperature histories (AD 1905-1978) using the chronologies of Savonlinna (SA), Pyhä-Häkki (PH) and Petkeljärvi (PJ). Alternative models made use of concurrent $\left(S A_{t}, P H_{t}, P J_{t}\right)$ and leading $\left(S A_{t-1}\right)$ increment data. Observed (thin black line) and reconstructed (thick grey line) temperatures are shown with the $99 \%$ (thin grey line) confidence intervals of the reconstruction. 
Table 3. Pearson correlations between the reconstructions based on the transfer functions (Table 2; Fig. 5) obtained using the MXD chronologies of Savonlinna (SA), Pyhä-Häkki (PH) and Petkeljärvi (PJ) and their combinations. Correlations were calculated over the calibration period (AD 19051978). All correlations were statistically significant $(p<0.001)$.

\begin{tabular}{|c|c|c|c|c|c|}
\hline Model & $\mathrm{SA}_{\mathrm{t}}, \mathrm{SA}_{\mathrm{t}-1}$ & $\mathrm{PH}_{\mathrm{t}}$ & $\mathrm{SA}_{\mathrm{t}}, \mathrm{PH}_{\mathrm{t}}$ & $\mathrm{PH}_{\mathrm{t}}, \mathrm{PJ}_{\mathrm{t}}$ & $\mathrm{SA}_{\mathrm{t}}, \mathrm{PH}_{\mathrm{t}}, \mathrm{PJ}_{\mathrm{t}}$ \\
\hline $\mathrm{SA}_{\mathrm{t}}, \mathrm{SA}_{\mathrm{t}-1}$ & 1 & & & & \\
\hline $\mathrm{PH}_{\mathrm{t}}$ & 0.432 & 1 & & & \\
\hline $\mathrm{SA}_{\mathrm{t}}, \mathrm{PH}_{\mathrm{t}}$ & 0.650 & 0.948 & 1 & & \\
\hline $\mathrm{PH}_{\mathrm{t}}, \mathrm{PJ}_{\mathrm{t}}$ & 0.531 & 0.949 & 0.924 & 1 & \\
\hline $\mathrm{SA}_{\mathrm{t}}, \mathrm{PH}_{\mathrm{t}}, \mathrm{PJ}_{\mathrm{t}}$ & 0.680 & 0.921 & 0.972 & 0.970 & 1 \\
\hline
\end{tabular}
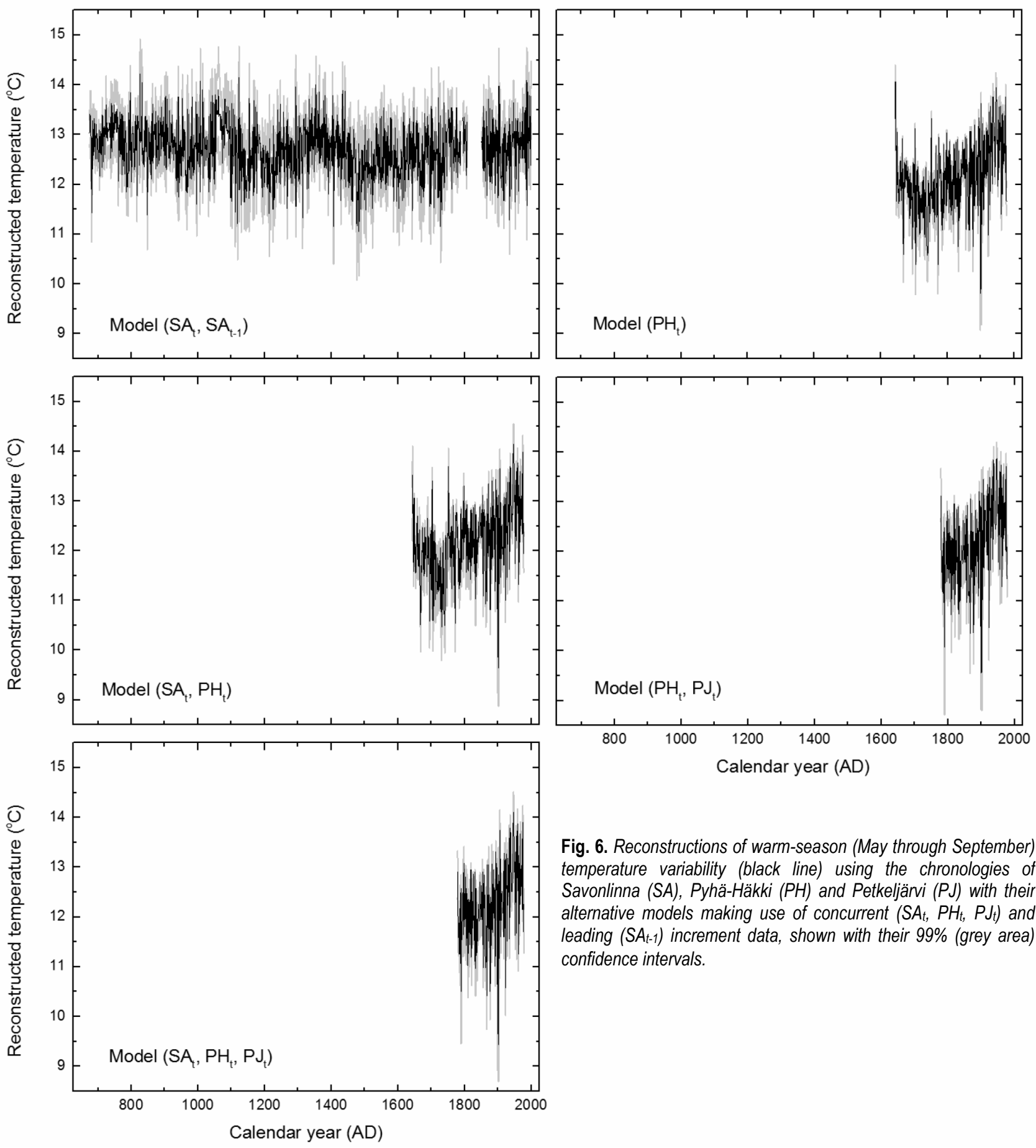

Fig. 6. Reconstructions of warm-season (May through September) temperature variability (black line) using the chronologies of Savonlinna (SA), Pyhä-Häkki (PH) and Petkeljärvi (PJ) with their alternative models making use of concurrent $\left(S A_{t}, P H_{t}, P J_{t}\right)$ and leading $\left(S A_{t-1}\right)$ increment data, shown with their $99 \%$ (grey area) confidence intervals. 
during the $18^{\text {th }}$ and $19^{\text {th }}$ centuries (Fig. 7a), with an increased occurrence of coldest years between the 17051902 (Table 4). Similarly, the coolest periods of 50- and 250-year length were recorded in AD 1704-1753 and in AD 1663-1912, respectively. Since the start of the record (AD 760), the temperature evolution exhibits a long-term negative trend with a slope of $-0.08^{\circ} \mathrm{C}\left(-0.12^{\circ} \mathrm{C}\right)$ per a century, until the year AD 2000 (AD 1900).

A new elongated palaeotemperature curve was correlated with the grid data (Tietäväinen et al., 2010) representing the meteorological site since AD 1883. Correlating the grid- and tree-ring based temperatures over the period AD 1883-1904 yielded a coefficient of 0.753, exemplifying that the reconstruction explained 56.6 percent of the instrumental temperature variance. Thus, the correspondence between the instrumental and reconstructed temperature was even higher during the precalibration than over the actual calibration period (see Table 2). Second, the reconstruction was compared with the available long instrumental temperature records in the region and adjacent areas since the 1740s (Table 5). Correlating reconstruction with these instrumental records over the full period showed positive and markedly high coefficients with all localities, the highest correlations appearing with the record from St. Petersburg. Comparison between the modern and early periods showed correlations approximating 0.7 for the former period, whereas the correlations over the latter averaged 0.6 among the four localities, St. Petersburg, Turku, Uppsala and Stockholm. These correlations evidenced the positive skill of the new palaeotemperature curve to reconstruct warm-season temperatures over an extended area at least over the past two and half centuries.

\section{Tree-ring proxy comparisons}

The new reconstruction was additionally compared with the tree-ring based evidence of summer temperatures as previously reconstructed in northern Finland and Fennoscandia using tree-ring width (TRW; Helama et al., 2010a) and MXD chronologies (Esper et al., 2012). The

Table 4. The years with the warmest (a) and coldest (b) warm-season (May through September) temperatures in southern Finland shown with their reconstructed temperature $\left({ }^{\circ} \mathrm{C}\right)$ estimates.

\begin{tabular}{cc|cc}
\hline \multicolumn{2}{c|}{$(\mathbf{a})$} & \multicolumn{2}{c}{$(\mathbf{b})$} \\
\hline Year & ${ }^{\circ} \mathbf{C}$ & Year & ${ }^{\circ} \mathbf{C}$ \\
\hline 826 & 15.46 & 1705 & 9.41 \\
1123 & 15.34 & 1772 & 9.42 \\
1986 & 15.24 & 1902 & 9.44 \\
1007 & 15.21 & 1867 & 9.53 \\
1988 & 15.15 & 1877 & 9.55 \\
832 & 15.14 & 1483 & 9.61 \\
1354 & 15.08 & 1899 & 9.65 \\
1293 & 15.00 & 1740 & 9.69 \\
1014 & 14.91 & 1741 & 9.73 \\
1061 & 14.89 & 1407 & 9.81 \\
\hline
\end{tabular}

three reconstructions showed generally similar temperature variability, although there appeared also dissimilarities (Fig. 7b). The smoothed reconstruction from southern Finland correlates positively with corresponding northern MXD and TRW reconstructions, with coefficients of $0.420(p=0.0138)$ and $0.377(p=0.0143)$, respectively. A slightly improved association between the northern and southern MXD reconstructions, in compari-

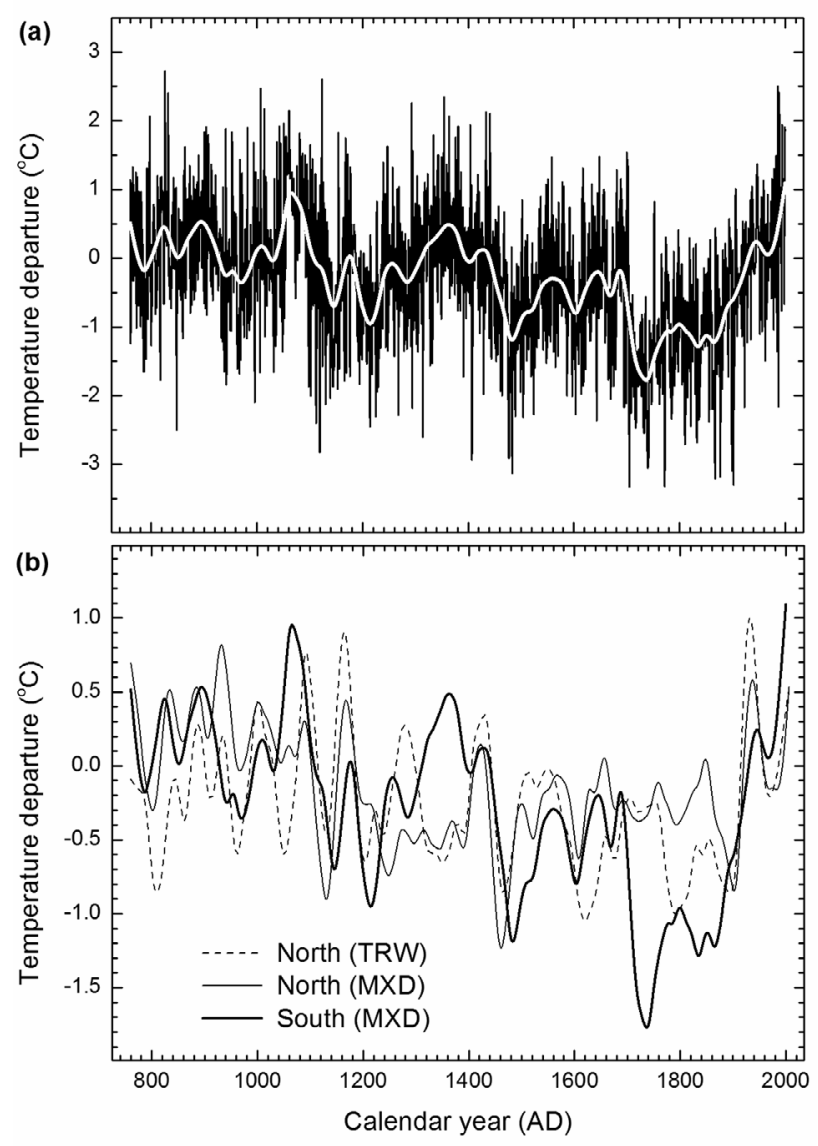

Fig. 7. Palaeotemperature curve for southern Finland from maximum density (MXD) chronologies shown with the annual (black line) and long-term (white line; smoothed using 50-year spline) (a). Comparison of reconstructed temperature variability based on the MXD chronologies from southern Finland (this study) and northern Fennoscandian (Esper et al., 2012) and as reconstructed from tree-ring width (TRW) chronology (Helama et al., 2010a) (b).

Table 5. Pearson correlations between the new reconstruction and long instrumental temperature (April through September) records over their full (1748-2000), modern (1873-2000), and early (1748-1822) periods.

\begin{tabular}{lccc}
\hline & Full period & Modern period & Early period \\
\hline St. Petersburg & 0.625 & 0.714 & 0.530 \\
Turku & 0.450 & 0.718 & 0.649 \\
Uppsala & 0.470 & 0.701 & 0.608 \\
Stockholm & 0.497 & 0.702 & 0.673 \\
\hline
\end{tabular}


son to the correlation between the northern TRW and southern MXD reconstructions, likely indicates a more consistent proxy signal among the same tree-ring parameter. These figures could be compared with the correlation between the two northern reconstructions (TRW and MXD) exhibiting even a higher coefficient of 0.540 $(p<0.001)$. Compared to their correlativity, the northsouth association was conceivably reduced by the proxy deviations occurring as the warmness and coolness of the $14^{\text {th }}$ and $18^{\text {th }} / 19^{\text {th }}$ centuries, respectively (Fig. $7 \mathrm{~b}$ ), during which the northern reconstructions did not indicate similarly anomalous temperatures.

\section{DISCUSSION AND CONCLUSIONS}

Our tree-ring record provided the first millennial reconstruction of summer temperatures using MXD data in southern Finland. The reconstruction was enabled by the high correlation between the warm-season temperatures and MXD formation (Fig. 4; Table 1). These findings highlight the climate-growth relationships with a notable temperature control on the late growing-season wood cell thickening in this region (Briffa et al., 2002a; Helama et al., 2012a, 2013a). Radial growth, by contrast, and therefore the variation of wide and narrow annual rings (and especially width of their earlywood portion) is positively depending on precipitation in the early part of the growing season (Henttonen, 1984; Miina, 2000; Helama et al., 2005a, 2009c). Nearly identical dendroclimatic circumstances were exemplified to prevail for Scots pine in Central Caucasus where the growth of TRW responded positively with summer (June through July) precipitation and the production of MXD reflected even more strongly the warm-season (April through October) temperatures (Brugnoli et al., 2010). Despite the relatively strong dendroclimatic association shown here, it is noteworthy that the timberline MXD data exhibts even higher correlation to summer temperatures. In comparison to the $\mathrm{R}^{2}$ of this study (see Table 2), the timberline MXD chronologies have shown to explain around $55-70 \%$ of the temperature variance in northern Fennoscandia (Schweingruber et al., 1988; Briffa et al., 1992; Esper et al., 2012).

Previously, the modern part of record as the living trees of the PH and PJ chronologies have constituted local dendroclimatic proxies in large-scale temperature reconstructions (Schweingruber et al., 1991; Briffa et al., 2002a, 2002b). Here we have complemented the use of living-tree MXD by extending the chronology backwards in time using the MXD measurements from subfossil pine remains (Helama et al., 2008b, 2010c, 2012a) and the obtained warm-season temperature reconstruction spans continuously over the period of AD 674-2010. The present reconstruction depicted multi-centennial warmth spanning from the $9^{\text {th }}$ to the $12^{\text {th }}$ century. Moreover, the long-term cooling since the Medieval time until the end of the $19^{\text {th }}$ century was parallel as observed in the MXD and multi-proxy records of northern Fennoscandia (Esper et al., 2012; Helama et al., 2010a) and Northern Hemisphere (Mann et al., 1999). The periods of the past climate that constitute these changes have been termed the Medieval Climate Anomaly (MCA) and the Little Ice Age (LIA).

The wamth around the turn of the first millennium $\mathrm{AD}$ was seen closely synchronous with the MXD and TRW evidence from northern Fennoscandia (Grudd, 2008; Esper et al., 2012) and northern Finland (Helama et al., 2009a, 2009b, 2010a, 2010b, 2012b). The northern MXD (Esper et al., 2012) and TRW (Helama et al., 2010a) reconstructions showed their warmest 250-year periods in AD 816-1065 and AD 932-1181, respectively. That is, the earlier warmness in the northern MXD reconstruction overlapped substantially with the warm period in the southern reconstruction that took place between the years AD 862 and 1111. Similarly, the warmth appears coeval to proxy-based hemispheric climate records that show evidence concerning the relatively warm conditions during the same centuries (Ljungqvist et al., 2012).

During the following centuries, the concentration of markedly cool periods was recorded from the $17^{\text {th }}$ to the early $20^{\text {th }}$ century, this period agreeing notably with the wide-spread climatic cooling between AD 1570 and 1900 when Northern Hemisphere summer temperatures fell significantly below their recent (AD 1961-1990) mean level (Matthews and Briffa, 2005). The coolest 250-year periods were evident in the northern MXD (Esper et al., 2012) and TRW (Helama et al., 2010a) reconstructions in AD 1228-1477 and AD 1601-1850, respectively. That is, the later coolness as implied by the northern TRW reconstruction more closely followed the reconstructed coolness by the southern MXD reconstruction in AD 1663 1912. With regards to the $20^{\text {th }}$ century conditions, all three reconstructions exhibited rising temperatures since the last decade of the $19^{\text {th }}$ century until the 1930 s warmth and towards the end of the century (Fig. $7 \mathrm{~b}$ ). Consistently with the obtained reconstructions, the cool LIA climate has been followed by warmer temperatures during the $20^{\text {th }}$ century (Tietäväinen et al., 2010), these climatic fluctuations thus comprising the reconstructed warmcool-warm cycle over the past millennium.

Our coolest temperatures during the LIA were reconstructed AD 1704 and 1753. This interval was synchronous, albeit slightly post-dating, the period of the Maunder Minimum (AD 1645 to 1715) (Eddy, 1976), and especially with the late Maunder Minimum (AD 16751715) that have been denoted the climax of the LIA in Europe (Luterbacher et al., 2001). This was a period during which the overall activity of the Sun was drastically reduced and sunspots virtually disappeared (Hoyt and Schatten, 1998). According to Luterbacher et al. (2001), the springs were likely cold and summers cooler than they are today in western, central and northern Europe. Combined use of climate models and palaeoclimate data suggested that regional cooling could be expected over the study region approximately two decades after the 
solar irradiance decreases, this mechanism involving inertia in the oceanic response and shift towards the negative phase in the atmospheric oscillations pattern over the North Atlantic and European land areas (Shindell et al., 2001). Similar atmospheric patterns, possibly coupled with the solar irradiation variations, have generally been suggested forcing the cooler and wetter summer-time climates in the study region during the LIA (Helama et al., 2009c; Luoto and Helama, 2010). The suggested lag in climatic response (Shindell et al., 2001) would further validate our observation of the delayed regional cooling to the Maunder Minimum reduction of solar activity.

Previous studies have linked the annual-scale palaeotemperature coolings with the climatic effects of the known explosive volcanic eruptions (Helama et al., 2013b; Jones et al., 2013). Interestingly, all of the ten coolest years among the reconstruction occurred during the 500-year period between the years AD 1407 and 1902 (Table 4). As mentioned above, this period overlapped with the LIA during which the wide-spread climatic cooling prevailed over the northern Hemisphere (Matthews and Briffa, 2005). Also, the coolness of the climate during the LIA may have likewise resulted from a relative abundance of major explosive volcanic eruptions (Bradley and Jones, 1993). Comparison with the evidence of late Holocene eruptions since AD 1400 (Briffa et al., 1998) indicates, however, that only the years 1740-1741 in our list (Table 4) could be traced to consistently follow any large explosive volcanic eruption. This would suggest a climatic cooling in the study region following the Shikotsu (Tarumai) eruption on Hokkaido, Japan, in AD 1739.

Moreover, among the recorded annual events (Table 4) the year $\mathrm{AD} 1867$ appears a year with severe crop failures and famine in large areas in Finland (Jutikkala, 2003a, 2003b). Historical documents tell that the winter that seemed to continue until mid June was followed by cold spring conditions and May temperatures seven degrees cooler than the long-term average, while it was also snowing intensively and sleeting even in the southern parts of Finland until May $25^{\text {th }}$ with fathom deep snowpack in areas where oats should be already sown, these climatic phenomena resulting in severe crop failures (Melander and Melander, 1928). According to the multiproxy reconstruction of late-winter and spring temperatures (February through June) in southern Finland, the year AD 1867 was third coldest since AD 1750 (Holopainen et al., 2009). Also the years AD 1705, 1740, 1772, 1899 and 1902 (Table 4) have been mentioned with devastating impacts of crop failures and famine in Finnish history of agriculture (Melander and Melander, 1928), and the year AD 1877 as one of the coldest late-winter and spring seasons over the past 260 years (Holopainen et al., 2009). These findings were in accordance with earlier considerations (Mikola, 1950) that Finnish tree-ring evidence may be comparable with historical dates of famine when the crop failures had been caused by cool summertime temperatures.

\section{ACKNOWLEDGEMENTS}

We are grateful to Professor Heli Peltola for measuring the samples by X-ray microdensitometry (ITRAX). Two anonymous referees are acknowledged. This study was supported by the Academy of Finland (\#251441) and Koneen Säätiö.

\section{REFERENCES}

Ahti T, Hämet-Ahti L and Jalas J, 1968. Vegetation zones and their sections in northwestern Europe. Annales Botanici Fennici 3:169211 .

Aniol RW, 1983. Tree-ring analysis using CATRAS. Dendrochronologia 1: 45-53.

Bartholin T, 1987. Dendrochronology in Sweden. Annales Academiae Scientiarum Fennicae 145: 79-88.

Bergsten U, Lindeberg J, Ringdby A and Evans R, 2001. Batch measurements of wood density on intact or prepared drill cores using Xray microdensitometry. Wood Science and Technology 35: 435452, DOI 10.1007/s002260100106.

Bradley RS, 1999. Paleoclimatology: reconstructing climates of the Quaternary. London, Academic Press: 613pp.

Bradley RS and Jones PD, 1993. 'Little Ice Age' Summer Temperature Variations: Their Nature and Relevance to Recent Global Warming Trends. The Holocene 3(4): 367-376, DOI 10.1177/095968369300300409.

Briffa KR, Jones PD, Bartholin TS, Eckstein D, Schweingruber FH, Karlén W, Zetterberg P and Eronen M, 1992. Fennoscandian summers from AD 500: temperature changes on short and long timescales. Climate Dynamics 7(3): 111-119, DOI 10.1007/BF00211153.

Briffa KR, Jones PD, Pilcher JR and Hughes MK, 1988. Reconstructing summer temperatures in northern Fennoscandinavia back to A.D. 1700 using tree-ring data from Scots pine. Arctic and Alpine Research 20(4): 385-394.

Briffa KR, Jones PD, Schweingruber FH and Osborn TJ, 1998. Influence of Volcanic Eruptions on Northern Hemisphere Summer Temperature over the Past 600 Years. Nature 393: 450-455, DOI 10.1038/30943.

Briffa KR, Osborn TJ, Schweingruber FH, Jones PD, Shiyatov SG and Vaganov EA, 2002a. Tree ring width and density data around the Northern Hemisphere. Part 1. Local and regional climate signals. The Holocene 12(6): 737-751, DOI 10.1191/0959683602hl587rp.

Briffa KR, Osborn TJ, Schweingruber FH, Jones PD, Shiyatov SG and Vaganov EA, 2002b. Tree ring width and density data around the Northern Hemisphere. Part 2. Spatio-temporal variability and associated climate patterns. The Holocene 12(6): 759-789, DOI 10.1191/0959683602hl588rp.

Brugnoli E, Solomina O, Spaccino L and Dolgova E, 2010. Climate signal in the ring width, density and carbon stable isotopes in pine (Pinus silvestris L.) in Central Caucasus. Geography, Environment, Sustainability 3: 4-16.

Büntgen U, Raible CC, Frank D, Helama S, Cunningham L, Hofer D, Nievergelt D, Verstege A, Timonen M, Stenseth NC and Esper J, 2011. Causes and Consequences of Past and Projected Scandinavian Summer Temperatures, 500-2100 AD. PLoS ONE 6(9): e25133, DOI 10.1371/journal.pone.0025133.

Burg JP, 1978. A new analysis technique for time series data. In: Childers DG, ed, Modern Spectrum Analysis. New York, IEEE Press, $42-48$.

Cook ER and Peters K, 1981. The smoothing spline: a new approach to standardizing forest interior tree-ring width series for dendroclimatic studies. Tree Ring Bulletin 41: 45-53. 
Cook E, Shiyatov S and Mazepa V, 1990. Estimation of the mean chronology. In: Cook E and Kairiukstis LA, eds, Methods of dendrochronology: applications in the environmental science. Dordrecht, Kluwer Academic Publishers, 123-132.

Ebisuzaki W, 1997. A method to estimate the statistical significance of a correlation when the data are serially correlated. Journal of Climate 10(9): 2147-2153, DOI 10.1175/15200442(1997)010<2147:AMTETS > 2.0.CO;2.

Eddy JA, 1976. The Maunder Minimum. Science 192: 1189-1202, DOI 10.1126/science.192.4245.1189.

Efron B and Tibshirani R, 1986. Bootstrap Methods for Standard Errors, Confidence Intervals, and Other Measures of Statistical Accuracy. Statistical Science 1: 54-75, DOI 10.1214/ss/1177013815.

Eronen M, Hyvärinen H and Zetterberg P, 1999. Holocene humidity changes in northern Finnish Lapland inferred from lake sediments and submerged Scots pines dated by tree rings. The Holocene 9(5): 569-580, DOI 10.1191/095968399677209885.

Eronen M, Zetterberg P, Briffa KR, Lindholm M, Meriläinen J and Timonen M, 2002. The supralong Scots pine treering record for Finnish Lapland: part 1, chronology construction and initial references. The Holocene 12(6): 673-680, DOI 10.1191/0959683602hl580rp.

Esper J, Frank DC, Timonen M, Zorita E, Wilson RJS, Luterbacher J, Holzkämper S, Fischer N, Wagner S, Nievergelt D, Verstege A and Büntgen U, 2012. Orbital forcing of tree-ring data. Nature Climate Change 2: 862-866, DOI 10.1038/nclimate1589.

Fritts HC, 1976. Tree rings and climate. New York, Academic Press: $567 \mathrm{pp}$.

Gordon GA, Gray BM and Pilcher JR, 1982. Verification of dendroclimatic reconstructions. In: Hughes MK, Kelly PM, Pilcher JR and LaMarche Jr. VC, eds, Climate from Tree Rings. Cambridge, Cambridge University Press, 115-132.

Grissino-Mayer HD and Fritts HC, 1997. The International Tree-Ring Data Bank: an enhanced global database serving the global scientific community. The Holocene 7(2): 235-238, DOI $10.1177 / 095968369700700212$.

Grudd H, 2008. Torneträsk tree-ring width and density AD 500-2004: a test of climatic sensitivity and a new 1500-year reconstruction of north Fennoscandian summers. Climate Dynamics 31(7-8): 843857, DOI 10.1007/s00382-007-0358-2.

Grudd H, Briffa KR, Gunnarson BE and Linderholm HW, 2000. Swedish tree rings provide new evidence in support of a major, widespread environmental disruption in 1628 BC. Geophysical Research Letters 27: 2957-2960, DOI 10.1029/1999GL010852.

Grudd H, Briffa KR, Karlén W, Bartholin TS, Jones PD and Kromer B, 2002. A 7400-year tree-ring chronology in northern Swedish Lapland: natural climatic variability expressed on annual to millennial timescales. The Holocene 12(6): 657-665, DOI 10.1191/0959683602hl578rp.

Gunnarson BE, Linderholm HW and Moberg A, 2011. Improving a tree-ring reconstruction from west-central Scandinavia: 900 years of warm-season temperatures. Climate Dynamics 36(1-2): 97-108, DOI 10.1007/s00382-010-0783-5.

Helama S, Arentoft BW, Collin-Haubensak O, Hyslop MD, Brandstrup CK, Mäkelä HM, Tian QH and Wilson R, 2013a. Dendroclimatic signals deduced from riparian versus upland forest interior pines in North Karelia, Finland. Ecological Research 28(6): 1019-1028, DOI 10.1007/s11284-013-1084-3.

Helama S, Bégin $Y$, Vartiainen $M$, Peltola $H$, Kolström $T$ and Meriläinen J, 2012a. Quantifications of dendrochronological information from contrasting microdensitometric measuring circumstances of experimental wood samples. Applied Radiation and Isotopes 70(6): 1014-1023, DOI 10.1016/j.apradiso.2012.03.025.

Helama S, Holopainen J, Macias-Fauria M, Timonen M and Mielikäinen K, 2013b. A chronology of climatic downturns through the mid- and late- Holocene: tracing the distant effects of explosive eruptions from palaeoclimatic and historical evidence in northern Europe. Polar Research 32: 15866, DOI 10.3402/polar.v32i0.15866.

Helama S, Lindholm M, Meriläinen J, Timonen M and Eronen $\mathrm{M}$, 2005a. Multicentennial ring-width chronologies of Scots pine along north-south gradient across Finland. Tree-ring Research 61: 21-32, DOI 10.3959/1536-1098-61.1.21.

Helama S, Lindholm M, Timonen M, Meriläinen J and Eronen M, 2002. The supra-long Scots pine tree-ring record for Finnish Lapland: Part 2, interannual to centennial variability in summer temperatures for 7500 years. The Holocene 12(6): 681-687, DOI 10.1191/0959683602hl581rp.

Helama S, Macias Fauria M, Mielikäinen K, Timonen M and Eronen M, 2010a. Sub-Milankovitch solar forcing of past climates: mid and late Holocene perspectives. Geological Society of America Bulletin 122(11-12): 1981-1988, DOI 10.1130/B30088.1.

Helama S, Makarenko NG, Karimova LM, Kruglun OA, Timonen M, Holopainen J, Meriläinen J and Eronen M, 2009a. Dendroclimatic transfer functions revisited: Little Ice Age and Medieval Warm Period summer temperatures reconstructed using artificial neural networks and linear algorithms. Annales Geophysicae 27(3):10971111, DOI 10.5194/angeo-27-1097-2009.

Helama S, Mielikäinen K, Timonen M and Eronen M, 2008a. Finnish supra-long tree-ring chronology extended to 5634 BC. Norwegian Journal of Geography 62(4): 271-277, DOI 10.1080/00291950802517593.

Helama S, Seppä H, Birks HJB and Bjune AE, 2010b. Reconciling pollen-stratigraphical and tree-ring evidence for high- and lowfrequency temperature variability in the past millennium. Quaternary Science Reviews 29(27-28): 3905-3918, DOI 10.1016/j.quascirev.2010.09.012.

Helama S, Seppä H, Bjune AE and Birks HJB, 2012b. Fusing pollenstratigraphic and dendroclimatic proxy data to reconstruct summer temperature variability during the past $7.5 \mathrm{ka}$ in subarctic Fennoscandia. Journal of Paleolimnology 48(1): 275-286, DOI 10.1007/s10933-012-9598-1.

Helama S, Timonen M, Holopainen J, Ogurtsov MG, Mielikäinen K, Eronen M, Lindholm M and Meriläinen J, 2009b. Summer temperature variations in Lapland during the Medieval Warm Period and the Little Ice Age relative to natural instability of thermohaline circulation on multi-decadal and multi-centennial scales. Journal of Quaternary Science 24(5): 450-456, DOI 10.1002/jqs.1291.

Helama S, Timonen M, Lindholm M, Meriläinen J and Eronen M, 2005b. Extracting long-period climate fluctuations from tree-ring chronologies over timescales of centuries to millennia. International Journal of Climatology 25(13): 1767-1779, DOI $10.1002 /$ joc. 1215.

Helama S, Meriläinen J and Tuomenvirta H, 2009c. Multicentennial megadrought in northern Europe coincided with a global El NiñoSouthern Oscillation drought pattern during the Medieval Climate Anomaly. Geology 37(2): 175-178, DOI 10.1130/G25329A.1.

Helama S, Vartiainen M, Kolström T and Meriläinen J, 2010c. Dendrochronological investigation of wood extractives. Wood Science and Technology 44(2): 335-351, DOI 10.1007/s00226-009-0293$\mathrm{y}$.

Helama S, Vartiainen M, Kolström T, Peltola H and Meriläinen J, 2008b. X-ray microdensitometry applied to subfossil tree-rings: growth characteristics of ancient pines from the southern boreal forest zone in Finland at intra-annual to centennial time-scales. Vegetation History and Archaeobotany 17(6): 675-686, DOI 10.1007/s00334-008-0147-9.

Henttonen H, 1984. The dependence of annual ring indices on some climatic factors. Acta Forestalia Fennica 186: 1-38.

Holmes RL, 1983. Computer-assisted quality control in tree-ring dating and measurement. Tree-Ring Bulletin 43: 69-78.

Holopainen J, 2004. The early climatological records of Turku. Finnish Meteorological Institute, Reports 2004/8: 1-59.

Holopainen J, Helama S, Kajander J M, Korhonen J, Launiainen J, Nevanlinna H, Reissell A and Salonen V-P, 2009. A multiproxy reconstruction of spring temperatures in south-west Finland since 1750. Climatic Change 92(1-2): 213-233, DOI 10.1007/s10584008-9477-y.

Hoyt DV and Schatten KH, 1998. Group Sunspot Numbers: A New Solar Activity Reconstruction. Solar Physics 179(1): 189-219, DOI 10.1023/A:1005007527816. 
Jones PD and Lister DH, 2002. The daily temperature record for St. Petersburg (1743-1996). Climatic Change 53(1-3): 253-267, DOI 10.1023/A:1014918808741.

Jones PD, Melvin TM, Harpham C, Grudd H and Helama S, 2013. Cool North European summers and possible links to explosive volcanic eruptions. Journal of Geophysical Research: Atmospheres 118(12): 6259-6265, DOI 10.1002/jgrd.50513.

Jutikkala E, 2003a. Halla aina uhkana (Frost as a constant threat in agriculture). Suomalaisen Kirjallisuuden Seuran toimituksia 914: 292-299.

Jutikkala E, 2003b. Katovuodet (Crop failure years). Suomalaisen Kirjallisuuden Seuran toimituksia 914: 504-513.

Koprowski M, Przybylak R, Zielski A and Pospieszyńska A, 2012. Tree rings of Scots pine (Pinus sylvestris L.) as a source of information about past climate in northern Poland. International Journal of Biometeorology 56(1): 1-10, DOI 10.1007/s00484-010-0390-5.

Läänelaid A, 2000. Five pine samples represent climate impact as well as eleven pines. University of Joensuu, Faculty of Forestry, Research Notes 108: 119-128.

Läänelaid A and Eckstein D, 2003. Development of a tree-ring chronology of Scots pine (Pinus sylvestris L.) for Estonia as a dating tool and climatic proxy. Baltic Forestry 9(2): 76-82.

Lappalainen M, 2001. Suomen kansallispuistot. Ulapalta paljakalle (Finland's National Parks - Seas of Blue, Seas of Green). Metsähallitus, Vantaa: 168 (in Finnish) pp.

Linderholm HW and Gunnarson BE, 2005. Summer temperature variability in central Scandinavia during the last 3600 years. Geografiska Annaler 87A: 231-241, DOI 10.1111/j.04353676.2005.00255.x.

Lindholm M, Meriläinen J and Eronen M, 1998-1999. A 1250-year ring-width chronology of Scots pine for south-eastern Finland, in the southern part of the boreal forest belt. Dendrochronologia 1617: $183-190$

Ljungqvist FC, Krusic PJ, Brattström G and Sundqvist HS, 2012. Northern Hemisphere temperature patterns in the last 12 centuries. Climate of the Past 8(1): 227-249, DOI 10.5194/cp-8-227-2012.

Luoto TP and Helama S, 2010. Palaeoclimatological and palaeolimnological records from fossil midges and tree-rings: the role of the North Atlantic Oscillation in eastern Finland through the Medieval Climate Anomaly and Little Ice Age. Quaternary Science Reviews 29(17-18): 2411-2423, DOI 10.1016/j.quascirev.2010.06.015.

Luterbacher J, Rickli R, Xoplaki E, Tinguely C, Beck C, Pfister C and Wanner H, 2001. The Late Maunder Minimum (1675-1715) - A Key Period for Studying Decadal Scale Climatic Change in Europe. Climatic Change 49(4): 441-462, DOI 10.1023/A:1010667524422.

Macias Fauria M, Grinsted A, Helama S, Moore J, Timonen M, Martma T, Isaksson E and Eronen M, 2010. Unprecedented low twentieth century winter sea ice extent in the Western Nordic Seas since A.D. 1200. Climate Dynamics 34(6): 781-795, DOI 10.1007/s00382-009-0610-z.

Macias-Fauria M, Grinsted A, Helama S and Holopainen J, 2012. Persistence matters: Estimation of the statistical significance of paleoclimatic reconstruction statistics from autocorrelated time series. Dendrochronologia 30(2): 179-187, DOI 10.1016/j.dendro.2011.08.003.

Mann ME, Bradley RS and Hughes MK, 1999. Northern Hemisphere Temperatures During the Past Millennium: Inferences, Uncertain- ties, and Limitations. Geophysical Research Letters 26(6): 759762, DOI 10.1029/1999GL900070.

Matthews JA and Briffa KR, 2005. The 'Little Ice Age': Reevaluation of an Evolving Concept. Geografiska Annaler 87A: 17-36, DOI 10.1111/j.0435-3676.2005.00242.x.

Melander KR and Melander G, 1928. Katovuosista Suomessa. In: Krohn K, ed, Oma maa $V$. Porvoo, Werner Söderström Osakeyhtiö, 350-359 (In Finnish).

Meriläinen J and Timonen M, 2004. Tree-ring data bank of Saima centre for environmental sciences in Savonlinna [Contribution to The International Tree-Ring Data Bank]

Miina J, 2000. Dependence of tree-ring, earlywood and latewood indices of Scots pine and Norway spruce on climatic factors in eastern Finland. Ecological Modelling 132(3): 259-273, DOI 10.1016/S0304-3800(00)00296-9.

Mikola P, 1950. Tree growth in years of crop failure. Metsätaloudellinen aikakauslehti 67: 204-205.

Moberg A and Bergström H, 1997. Homogenization of Swedish temperature data. Part III: The long temperature records from Uppsala and Stockholm. International Journal of Climatology 17(7): 667699, DOI 10.1002/(SICI)1097-0088(19970615)17:7<667::AIDJOC115>3.0.CO;2-J.

Osborn TJ, Briffa KR and Jones PD, 1997. Adjusting variance for sample size in tree ring chronologies and other regional mean timeseries. Dendrochronologia 15: 89-99.

Peltola H, Kilpeläinen A, Sauvala K, Räisänen T and Ikonen V-P, 2007. Effects of early thinning regime and tree status on the radial growth and wood density of Scots pine. Silva Fennica 41(3): 489505, DOI 10.14214/sf.285.

Schweingruber FH, Bartholin TS, Schär E and Briffa KR, 1988. Radiodensitometric-dendroclimatological conifer chronologies from Lapland (Scandinavia) and the Alps (Switzerland). Boreas 17(4): 559-566, DOI 10.1111/j.1502-3885.1988.tb00569.x.

Schweingruber FH, Bräker OU and Schär E, 1987. Temperature information from a European dendroclimatological sampling network. Dendrochronologia 5: 9-33.

Schweingruber FH, Briffa KR and Jones PD, 1991. Yearly maps of summer temperatures in western Europe from A.D. 1750 to 1975 and western North America from 1600 to 1982. Results of a radiodensitometrical study on tree rings. Vegetatio 92(1): 5-71, DOI 10.1007/BF00047132.

Shindell DT, Schmidt GA, Mann ME, Rind D and Waple A, 2001. Solar Forcing of Regional Climate Change During the Maunder Minimum. Science 294: 2149-2152, DOI 10.1126/science. 1064363 .

Tietäväinen H, Tuomenvirta $\mathrm{H}$ and Venäläinen $\mathrm{A}, 2010$. Annual and seasonal mean temperatures in Finland during the last 160 years based on gridded temperature data. International Journal of Climatology 30(15): 2247-2256, DOI 10.1002/joc.2046.

Virkkala R, Korhonen KT, Haapanen R and Aapala K, 2000. Protected forests and mires in forest and mire vegetation zones in Finland based on the 8th National Forest Inventory. The Finnish Environment 395: 1-49.

Walker MJC, 2005. Quaternary Dating Methods. Chichester, Wiley: 286pp.

Warren WG, 1980. On removing the growth trend from dendrochronological data. Tree Ring Bulletin 40: 35-44. 